OPEN ACCESS

Edited by:

Richard Sayre,

New Mexico Consortium at Los

Alamos National Labs, USA

Reviewed by:

Ghulam K. A. Parveez,

Malaysian Palm Oil Board, Malaysia

Taras P. Pasternak,

Institute of Biology II, Germany

*Correspondence:

Li-Juan Qiu

qiulijuan@caas.cn

${ }^{\dagger}$ These authors have contributed equally to this work.

Specialty section:

This article was submitted to

Plant Biotechnology,

a section of the journal

Frontiers in Plant Science

Received: 14 February 2015 Accepted: 28 September 2015 Published: 15 October 2015

Citation:

Guo B, Guo Y, Hong H, Jin L,

Zhang L, Chang R-Z, Lu W, Lin M and Qiu L-J (2015)

Co-expression of G2-EPSPS

and glyphosate acetyltransferase GAT genes conferring high tolerance

to glyphosate in soybean.

Front. Plant Sci. 6:847.

doi: 10.3389/fpls.2015.00847

\section{Co-expression of G2-EPSPS and glyphosate acetyltransferase GAT genes conferring high tolerance to glyphosate in soybean}

\author{
Bingfu Guo ${ }^{1,2+}$, Yong Guo ${ }^{1 \dagger}$, Huilong Hong ${ }^{1,2}$, Longguo Jin ${ }^{1}$, Lijuan Zhang ${ }^{1}$, \\ Ru-Zhen Chang ${ }^{1}$, Wei Lu ${ }^{3}$, Min Lin ${ }^{3}$ and Li-Juan Qiu ${ }^{1 *}$ \\ ${ }^{1}$ The National Key Facility for Crop Gene Resources and Genetic Improvement, Institute of Crop Science, Chinese Academy \\ of Agricultural Sciences, Beijing, China, ${ }^{2}$ College of Agriculture, Northeast Agricultural University, Harbin, \\ China, ${ }^{3}$ Biotechnology Research Institute, Chinese Academy of Agricultural Sciences, Beijing, China
}

Glyphosate is a widely used non-selective herbicide with broad spectrum of weed control around the world. At present, most of the commercial glyphosate tolerant soybeans utilize glyphosate tolerant gene CP4-EPSPS or glyphosate acetyltransferase gene GAT separately. In this study, both glyphosate tolerant gene G2-EPSPS and glyphosate degraded gene GAT were co-transferred into soybean and transgenic plants showed high tolerance to glyphosate. Molecular analysis including PCR, Sothern blot, qRT-PCR, and Western blot revealed that target genes have been integrated into genome and expressed effectively at both mRNA and protein levels. Furthermore, the glyphosate tolerance analysis showed that no typical symptom was observed when compared with a glyphosate tolerant line HJ06-698 derived from GR1 transgenic soybean even at fourfold labeled rate of Roundup. Chlorophyll and shikimic acid content analysis of transgenic plant also revealed that these two indexes were not significantly altered after glyphosate application. These results indicated that co-expression of G2-EPSPS and GAT conferred high tolerance to the herbicide glyphosate in soybean. Therefore, combination of tolerant and degraded genes provides a new strategy for developing glyphosate tolerant transgenic crops.

Keywords: transgenic soybean, glyphosate tolerance, G2-EPSPS, GAT, chlorophyll content, shikimic acid

\section{INTRODUCTION}

Soybean [Glycine max (L.) Merr.], an important and most frequently cultivated grain legume in the worldwide, is the economic source of both vegetable oil and protein meal with about $20 \%$ oil and $40 \%$ protein content in its seeds (Hartman et al., 2011). Among them, about $95 \%$ of the oil fraction is consumed as edible oil and about $98 \%$ of soybean meal is used in livestock and aquaculture feeds due to its high protein level (Liu et al., 2008). Soybean is unique among crops in that it supplies protein nearly equal in quality to that of animal sources but with less saturated fat and no cholesterol (Young, 1991). In addition, it plays an important role in crop diversification and benefits to other

Abbreviations: AMPA, Aminomethylphosphonic acid; AS, Acetosyringone; DTT, Dithiothreitol; EPSPS, 5enolpyruvylshikimate-3-phosphate synthase; GAT, Glyphosate N-acetyltransferase; GOX, glyphosate oxidoreductase; GR1, First generation of glyphosate resistant crops; GR2, Second generation of glyphosate resistant crops; PVDF, Polyvinylidene difluoride; qRT-PCR, Quantitative real-time polymerase chain reaction. 
crops due to its capacity for addition of atmospheric nitrogen to the soil during crop rotation (Singh et al., 2010).

Weed is defined as plant whose undesirable qualities outweigh their good points (Randall, 1997). Weeds are troublesome in many ways, in which they mainly reduce crop yield by competing for light, water, soil nutrients, and space. Weeds are so common on cropland that their economic impact on crop losses and control costs has been estimated for different crops. In general, about $15 \%$ of soybean seed yield was reduced due to the harm of weeds (Yao, 2009). Therefore, weed control becomes a significant process for ensuring high and stable yield of crops. There are many methods available to control weeds, including preventative, cultural, mechanical, biological, and chemical weed control. Since chemical method is very economic, highly efficient and easy to operate, it has been an important strategy in modern weed management in crop field (Zhang, 2011). Based on expenditures, about 30 and $13 \%$ of global agrochemical sales are committed to the purchase of selective and non-selective herbicide respectively (Edwards and Hannah, 2014).

Along with the extensive use of herbicides, weeds were becoming widely resistant to commonly used selective herbicides. The ability to use glyphosate ( $N$-phosphonomethylglycine) in glyphosate-resistant (GR) crops made weed management easy, efficient, economical and environmentally compatible (Green, 2012). Glyphosate's mode of action is non-selectively inhibiting the plant enzyme 5-enolpyruvylshikimate-3-phosphate synthase (EPSPS) which involved in the biosynthesis pathway for aromatic amino acid (Padgette et al., 1995; Tan et al., 2006). Because of this mode of action, it is effective on actively growing plants, whether they are crops or weeds. The ability to use biotechnology to make glyphosate tolerant transgenic crops allows farmers to use glyphosate as a postemergence herbicide against both broadleaf and cereal weeds (Dill et al., 2008).

Up to now, two strategies for achieving glyphosate tolerance have been successfully applied in GM plants. The first one is overproduction of target enzyme EPSPS, such as expression of exogenous CP4-EPSPS (Meilan et al., 2002) or mutant EPSPS in transgenic plants (Tian et al., 2011). One of the disadvantages of this strategy is that glyphosate remains to be accumulated in plant tissues and decrease crop yield by interfering with the development of reproductive tissues (Pline et al., 2002). For example, although the labeled rate for glyphosate application in GR soybeans is varies from 600 to $1200 \mathrm{~g}$ a.e.ha $^{-1}$ and the tolerant level could reach to threefolds of labeled rate $(2400 \mathrm{~g}$ a.e. $\mathrm{ha}^{-1}$ ) at some growth stages, some physiological indexes including photosynthesis, nutrient accumulation, and nodulation in some cultivars was still reduced after receiving increasing glyphosate rates or applications at later growth stages (Gazziero et al., 2008; Zobiole et al., 2012). Meanwhile, the typical symptom, known as "yellow flashing," was observed in both GR1 and GR2 soybeans (Zobiole et al., 2012). This symptom is attributed to the decrease of chlorophyll content, accumulation of the primary phytotoxic metabolite or the formation of insoluble glyphosatemetal complexes (Campbell et al., 1976; Reddy et al., 2004; Zobiole et al., 2012). The second strategy is removal of herbicidal residue after detoxification it by glyphosate oxidoreductase (GOX) gene (Pedotti et al., 2009) or glyphosate $\mathrm{N}$-acetyltransferase (GAT) gene (Castle et al., 2004; Siehl et al., 2005). GOX is an enzyme which can degrade glyphosate and converting it to glyoxylate and aminomethylphosphonic acid (AMPA). Although AMPA is less phytotoxic than glyphosate to plant, it could still induce "yellow flashing" (Ding et al., 2011). Another enzyme GAT could degrade glyphosate residues by catalyzing acetylation of glyphosate. Therefore, overexpression of the GOX or GAT gene can also result in a relatively high level of glyphosate tolerance in different crops (Green et al., 2008; Hadi et al., 2012). Dun et al. (2014) compared the glyphosate tolerance of transgenic tobacco which expressed GAT and EPSPS alone or combination and the results suggested that co-expression of them showed the highest tolerance to glyphosate, providing a new method to develop high glyphosate tolerant crops by combination of different strategies.

In this study, both G2-EPSPS and GAT genes were co-transferred into soybean by Agrobacterium-mediated transformation method. Molecular and phenotype analysis revealed that co-expression of these two genes conferred high glyphosate tolerance. Especially, the high tolerant line of transgenic soybean did not show typical symptom of shikimic acid accumulation, "yellow flashing" and chlorophyll content reduction when compared with a GR1 cultivar HJ06-698. These results suggested that the new developed transgenic line with high tolerance to glyphosate could be used for soybean breeding.

\section{MATERIALS AND METHODS}

\section{Plant Materials and Vector Information}

Soybean cultivars Jack and ZH10, and the binary vector pKTrGE (Beijing Weiming Kaituo Biotech Co. Ltd, China), were used for transformation. Glyphosate tolerant soybean HJ06-698, a backcross cultivar derived from GTS40-3-2 (GR1 soybean), was used as positive control for glyphosate tolerance analysis. The pKT-rGE contains a GAT gene from Bacillus licheniformis and glyphosate tolerant gene (G2-EPSPS) from Pseudomonas fluorescens G2 driven by two CaMV 35S promoters separately (Figure 1A).

\section{Genetic Transformation}

The plant expression vector pKT-rGE was transformed into Agrobacterium strain Ag10. The Agrobacterium-mediated soybean cotyledonary node genetic transformation method was performed according to Guo et al. (2015) with some modification. Briefly, seedlings geminated from sterilized mature seeds on germination medium at $24^{\circ} \mathrm{C}$ for 5 days were used for preparing cotyledonary node explants. After the explants were infected with Agrobacterium suspensions supplemented with $0.02 \%$ Silwet L-77 and sonicated at $35 \mathrm{kHz}$ for $2 \mathrm{~s}$, they were placed on co-culture medium and incubated at $24^{\circ} \mathrm{C}$ in dark for 3 days. In order to improve the infection efficiency of Agrobacterium and inhibit the browning of explants, the coculture medium was supplemented with $40 \mu \mathrm{mol} \mathrm{L}^{-1}$ AS, $1 \mu \mathrm{mol}$ $\mathrm{L}^{-1}$ DTT, $1 \mu \mathrm{mol} \mathrm{L}{ }^{-1} \mathrm{Na}_{2} \mathrm{~S}_{2} \mathrm{O}_{3}$, and $8.8 \mu \mathrm{mol} \mathrm{L}{ }^{-1} \mathrm{~L}$-Cysteine. The glyphosate (Sigma-Aldrich, USA) with final concentrations of $15 \mathrm{mg}$ a.e. $\mathrm{L}^{-1}$ and $5 \mathrm{mg}$ a.e. $\mathrm{L}^{-1}$ were used for plant selection in the medium for bud induction and shoot elongation respectively. 
A

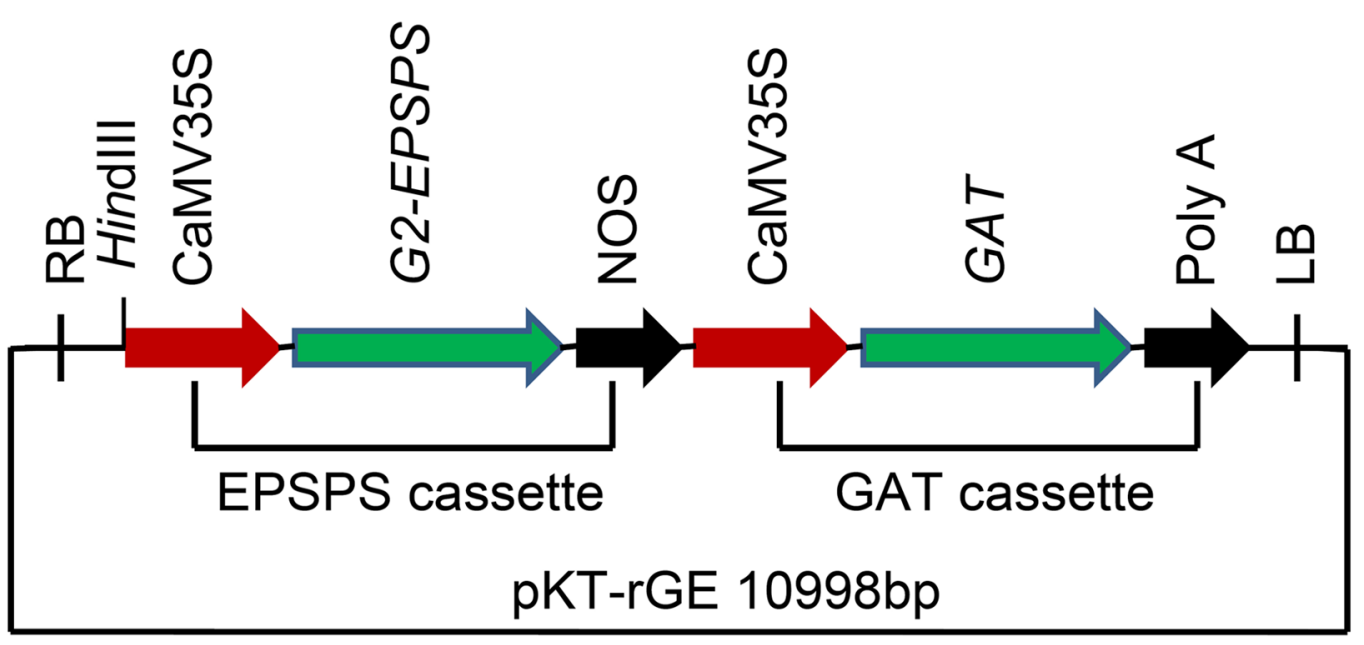

B

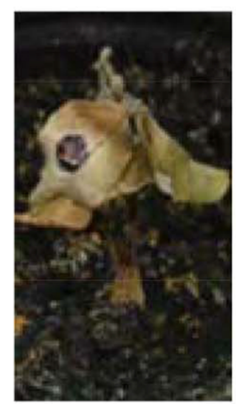

1

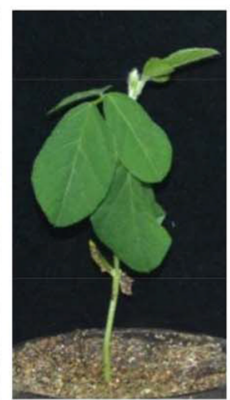

2

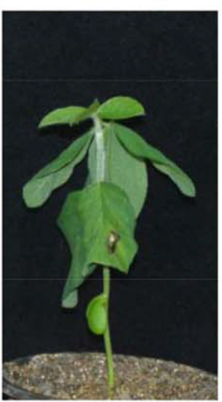

3

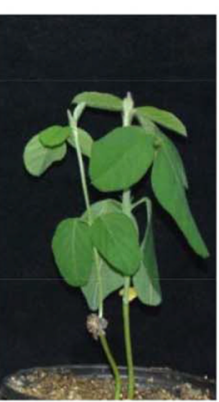

4

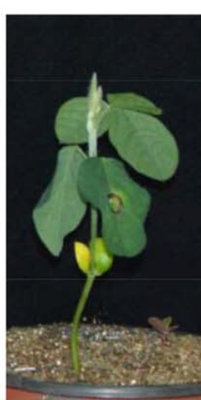

5

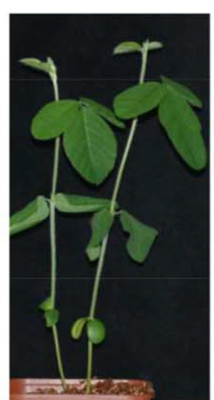

6

C

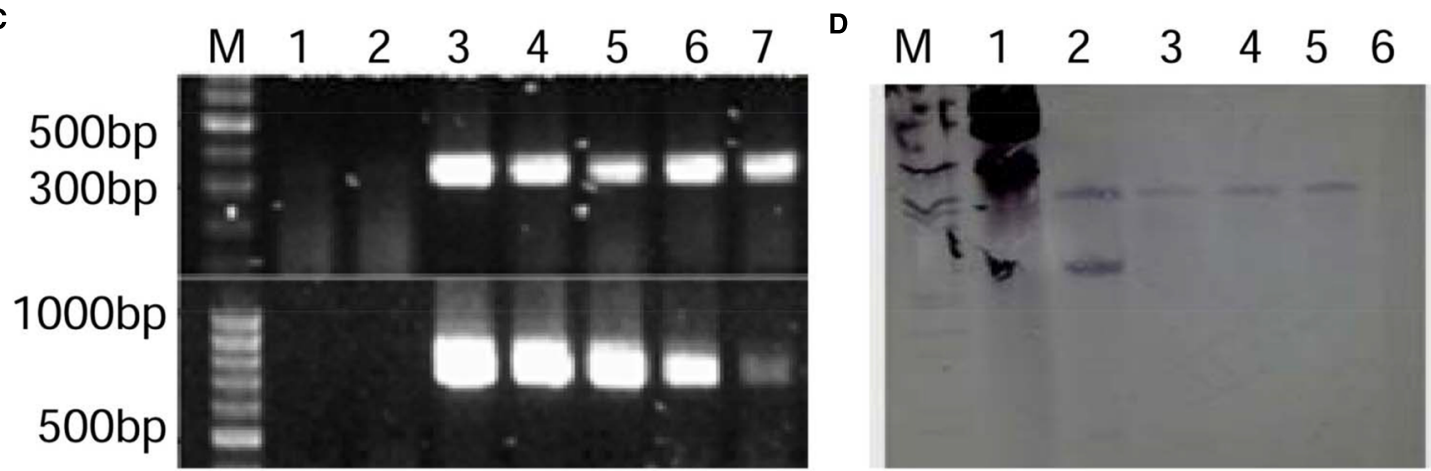

FIGURE 1 | Transformation vector and identification of transgenic $\mathbf{T}_{\mathbf{0}}$ lines. (A) Schematic representation of plant transformation vector (pKT-rGE) showing the two expression cassettes for G2-EPSPS and GAT genes. (B) Tolerant level of $\mathrm{T}_{0}$ putative transgenic plants identified by pipette spotting of $1 \mu \mathrm{l}$ Roundup (0.3 mg a.e. $\mu \mathrm{I}^{-1}$ glyphosate). 1: non-transgenic wild type soybean treated with Roundup; 2: non-transgenic soybean treated with water; 3-5: four putative transgenic lines treated with Roundup; 6: glyphosate tolerant soybean HJ06-698 treated with Roundup. (C) The glyphosate tolerant transgenic plants were confirmed by PCR analysis. M: 100 bp DNA marker; 1: negative control of non-transgenic receptor; 2: negative control of water; 3: positive control of pKT-rGE vector; 4-7: four putative transgenic plants. (D) Southern blot analysis of four glyphosate tolerance putative transgenic lines. M: DIG marker; 1: positive control of pKT-rGE Vector; 2-5: DNA samples of four putative transgenic plants digested with Hindlll; 6: DNA sample of non-transgenic soybean receptor was used as the negative control.

Putative transgenic soybean plants were selected from resistant bud induction, shoot elongation and rooting.

\section{Genomic DNA Extraction and PCR Amplification}

Genomic DNA was isolated from young leaves of putative transgenic plants using the modified CTAB method (Murray and
Thompson, 1980). A 743 bp fragment of G2-EPSPS and 338 bp of GAT were amplified using gene-specific primers (Table 1). The PCR reactions were carried out in a total volume of $20 \mu \mathrm{l}$ using PTC-200 Thermocycler (MJ Research/Bio-Rad, USA) with the PCR reaction cycles as follows: 1 cycle $\left(94^{\circ} \mathrm{C}, 4 \mathrm{~min}\right), 36$ cycles $\left(94^{\circ} \mathrm{C}, 30 \mathrm{~s} ; 60^{\circ} \mathrm{C}, 30 \mathrm{~s} ; 72^{\circ} \mathrm{C}, 45 \mathrm{~s}\right)$, and a final extension step $\left(72^{\circ} \mathrm{C}, 10 \mathrm{~min}\right)$. PCR products were analyzed on $1 \%$ agarose gels by electrophoresis. 
TABLE 1 | Primers used in this study

\begin{tabular}{|c|c|c|}
\hline $\begin{array}{l}\text { Primer } \\
\text { Name }\end{array}$ & Sequence $\left(5^{\prime}-3^{\prime}\right)$ & $\begin{array}{l}\text { Fragment } \\
\text { Length (bp) }\end{array}$ \\
\hline G2EP-F & 5'-ACCAGGAGCCTTGTACCTTGAG-3' & 743 \\
\hline G2EP-R & 5'-ATCGGGTTCGATCAGGTAATC-3' & \\
\hline GAT-F & $5^{\prime}$ - CTCAGACCAAACCAGCCGATAG -3' & 338 \\
\hline GAT-R & 5' - GTAGTAGCCTGAGGCGGATGTC C-3' & \\
\hline ACT-RTF & 5' - CGGTGGTTCTATCTTGGCATC -3' & 142 \\
\hline ACT-RTR & 5' - GTCTITCGCTTCAATAACCCTA-3' & \\
\hline CP4-RTF & 5' - GCAAATCCTCTGGCCTाTCC-3' & 146 \\
\hline CP4-RTR & 5' - CTTGCCCGTATTGATGACGTC -3' & \\
\hline G2EP-RTF & 5' - CGACATTACTTCCATCACAAGCA-3' & 150 \\
\hline G2EP-RTR & $5^{\prime}$ - CCCGAATCATCAGGCAAACA-3' & \\
\hline GAT-RTF & 5' - GCGGACTTGCTTTGGTGTAAT-3' & 168 \\
\hline GAT-RTR & 5'-AACTACTCACACATTATTATGGAGAAACT-3' & \\
\hline
\end{tabular}

\section{Southern Blotting}

Randomly-selected transgenic $\mathrm{T}_{0}$ plants confirmed by glyphosate tolerance and PCR analysis were analyzed by Southern blotting to check the integration of the exogenous genes. 40-60 $\mu \mathrm{g}$ genomic DNA (gDNA) from transgenic plants and receptor plants (negative control) were digested with restriction enzyme. To detect specific fragment for each T-DNA insertion, the restriction enzyme (HindIII) with only one cleave site in T-DNA region of pKT-rGE was used for digestion. gDNA after digestion were separated by agarose gel electrophoresis and was transferred to a nylon membrane by rapid downward transfer systems (Whatman/Schleicher \& Schuell) after electrophoresis. A DigdUTP probe for GAT coding sequence was amplified from $\mathrm{pKT}$ rGE plasmid using DIG Probe Synthesis Kit (Mylab Corporation, China) with gene specific primers GAT-F/R (Table 1). The vector was also digested with HindIII and an $11.0 \mathrm{~kb}$ fragment containing the GAT coding sequence could be hybridized by the probe. After hybridization, the bands on the membrane were detected with the chemi-color substrate NBT/BCIP (Mylab Corporation, China).

\section{Semi-quantitative RT-PCR and qRT-PCR}

Total RNA extracted from leaves of four transgenic lines with RNA extraction kit (TRIzol reagent, Invitrogen, Inc.) was used for semi-quantitative RT-PCR. For qRT-PCR, RNA was isolated from different tissues (young leaves, mature leaves, stem, flower, and seed) of Line 1 or leaves of Line 1 and HJ06-698 treated with $900 \mathrm{~g}$ a.e. $\mathrm{ha}^{-1}$ glyphosate at different time points $(0,6,12,24$, 48, 72, 120, and $192 \mathrm{~h}$ ). The cDNA was synthesized using the PrimerScript $^{\text {TM }}$ II 1st strand cDNA synthesis kit (Takara, Inc.)). Specific primers for G2-EPSPS and GAT genes were used for semiquantitative RT-PCR and qRT-PCR (Table 1). The expression levels of different genes were calculated using $2^{-\Delta \Delta t}$ method and standardized to the constitutive expression level of Actin (Kenneth and Schmittgen, 2001). At least three biological replications were carried out for each sample.

\section{Western Blotting}

About $0.1 \mathrm{~g}$ samples of leaves, roots and stem were ground in liquid nitrogen and total protein were extracted from four transgenic lines with plant protein extraction kit (Cwbiotech, Inc.,) in accordance with the manufacturer's instructions. The protein concentrations were measured using the Bradford method (Bradford, 1976). Equal amounts of proteins $(35 \mu \mathrm{g})$ were boiled at $95^{\circ} \mathrm{C}$ for $5 \mathrm{~min}$ with $1 / 4$ volume of $5 \times$ sodium dodecylsulfate loading buffer and separated on $10 \%$ gels using SDS-PAGE. Heat shock protein (HSP) was used as the reference protein for normalization of the protein level. The proteins were then transferred electrophoretically to a PVDF membrane with transfer buffer $\left(10 \mathrm{mmol} \mathrm{L}^{-1}\right.$ glycine, $25 \mathrm{mmol} \mathrm{L}^{-1}$ Tris, and 10\% (V/V) methanol, pH8.2) and then washed with $10 \mathrm{ml}$ TBS for $5 \mathrm{~min}$. After blocking with $5 \%$ dried skimmed milk (diluted by TTBS) for $1 \mathrm{~h}$ at room temperature, the membrane was incubated with antiserum (1:5000 dilution) for $1 \mathrm{~h}$ and then washed with 100-200 $\mathrm{ml}$ TTBS for three times (5 min each). Then, the membrane was incubated with 1:5000 diluted anti-rabbit IgG for $1 \mathrm{~h}$ at room temperature and washed with 100-200 ml TTBS for three times ( 5 min each). The reaction was visualized with ECL chemi-color substrate.

\section{Glyphosate Tolerance Analysis}

Commercially formulated isopropylamine salt of glyphosate with the rate of $300 \mathrm{~g}_{\text {a.e. }} \mathrm{L}^{-1}$ (Roundup, Monsanto Company) was used for glyphosate tolerance analysis. The labeled rate for glyphosate application in GR soybeans varies from 600 to $1200 \mathrm{~g}$ a.e.ha ${ }^{-1}$ (Gazziero et al., 2008) and the application label rate for the crop production region of our study site is $900 \mathrm{~g}^{\text {a.e.ha }}{ }^{-1}$ according to the manufacture's manual. Two methods including pipette spotting and spraying methods were used to analyze glyphosate tolerance in transgenic soybean plants. The first method was carried out for $\mathrm{T}_{0}$ plants and the other one was for $\mathrm{T}_{2}$ plants. For the pipette spotting method, $1 \mu \mathrm{l}$ of Roundup $\left(0.3 \mathrm{mg}\right.$ a.e. $\mu \mathrm{l}^{-1}$ glyphosate) was pipette spotted in young leaves after the rooting plantlets were transferred into pot culture. Glyphosate tolerance analysis of transgenic $\mathrm{T}_{2}$ plants was performed according to Zobiole et al. (2012) with some modification. When the first trifoliolate leaves of transgenic $\mathrm{T}_{2}$ plants were fully expanded, plants were spraying with Roundup at rates of 900, 1800, 2700, and $3600 \mathrm{~g}$ a.e.ha ${ }^{-1}$. The rates 2700 and $3600 \mathrm{~g}^{\text {a.e.ha }}{ }^{-1}$ was selected to represent the "worst-case scenario" to promote soybean injury. The phytotoxicity symptoms and survival number of glyphosate tolerance plants were investigated after 2 weeks.

\section{Chlorophyll Content Analysis}

Chlorophyll content was measured according to Richardson et al. (2002). Thirty-day old plants of transgenic line 1, HJ06-698, $\mathrm{ZH} 10$, and MD12 were spraying with Roundup at labeled rate of $900 \mathrm{~g}$ a.e.ha ${ }^{-1}$ using water as negative control. The SPAD value of leaves from different soybean plants were measured with a SPAD502 Plus chlorophyll measuring instrument at $0,6,12,24,48$, 72 , and $120 \mathrm{~h}$ after treatments. Absorption at 650 and $940 \mathrm{~nm}$ was used to estimate chlorophyll content. At least eight biological replications were performed for each treatment and the data was analyzed using SPSS 18.0 and Excel. The one way ANOVA was used for significant difference analysis. 


\section{Shikimic Acid Content Analysis}

The content of shikimic acid was measured according to Gao et al. (2013). Briefly, 30-day old soybeans of transgenic line 1, HJ06-698, ZH10, and MD12 were spraying with the Roundup at labeled rate of $900 \mathrm{~g}$ a.e.ha ${ }^{-1}$. After the application of glyphosate, $0.2 \mathrm{~g}$ leaves added with $1 \mathrm{ml}$ of $0.25 \mathrm{~mol} \mathrm{~L}^{-1} \mathrm{HCl}$ were grounded into homogenate suspension rapidly on ice. After the mixture was centrifuged at $14,000 \mathrm{rpm}$ for $15 \mathrm{~min}\left(4^{\circ} \mathrm{C}\right), 100 \mu \mathrm{l}$ of supernatant was taken and mixed with $2 \mathrm{ml}$ of $0.1 \%$ periodic acid to oxidize shikimic acid for $3 \mathrm{~h}$. Then, the reaction solution was mixed with $2 \mathrm{ml} \mathrm{NaOH}(0.1 \mathrm{~mol} / \mathrm{L})$ and $1.2 \mathrm{ml}$ glycine $(0.1 \mathrm{~mol} / \mathrm{L})$. Finally, the optical density of the solution was measured at $380 \mathrm{~nm}$. The content of shikimic acid was calculated according to the standard curve plotting by using standard samples at different concentrations. The one way ANOVA was used for significant difference analysis.

\section{RESULTS}

\section{Transformation and Molecular Analysis of Transgenic Soybean Plants}

Soybean plants were transformed with 35S-G2EPSPS/35S-GAT and a total of 22 independent putative transgenic lines were selected using Agrobacterium-mediated transformation method. After the rooting plantlets were transferred into pot culture, the $\mathrm{T}_{0}$ plants were initially confirmed by treatment with $1 \mu \mathrm{l}$ Roundup ( $0.3 \mathrm{mg}$ a.e. $\mu \mathrm{l}^{-1}$ glyphosate) in young leaves. Two weeks after the treatment, four transgenic soybeans were identified to show high tolerance to glyphosate compared to wild type control (Figure 1B).

In order to confirm the integration of exogenous genes in putative $T_{0}$ transgenic plants, PCR analysis and Southern blot were used for molecular analysis. Expected $743 \mathrm{bp}$ products (for G2-EPSPS gene) and 338 bp products (for GAT gene) were detected in all four $\mathrm{T}_{0}$ putative transgenic plants while no PCR product was detected in the non-transgenic control when using specific primers for both genes (Figure 1C). Moreover, Southern blot analysis of four glyphosate tolerance transgenic lines also suggested that G2-EPSPS/GAT were stably integrated into genome of these positive transgenic plants (Figure 1D).

\section{Expression Analysis of Transgene by Semi-quantitative RT-PCR and Western Blot}

Semi-quantitative RT-PCR was performed to detect the transcription level of G2-EPSPS and GAT genes in leaves of four transgenic plants. The transgenic lines showed accumulation of G2EPSPS/GAT transcript while the non-transgenic control did not show any specific band, indicating no transcript accumulation in the negative control (Figure 2A).

Western blot was also carried out to quantify the protein accumulation of G2EPSPS/GAT in different transgenic lines. The results revealed that different levels of G2EPSPS/GAT proteins were detected in all transgenic plants (Figure 2B). No protein expression was detected in non-transformed wild type plant. Especially, line 1 and line 2 showed highest protein expression level either for G2EPSPS or GAT and line 1 was selected for further analysis.

\section{Glyphosate Tolerance Analysis of Transgenic Soybean}

In order to detect the glyphosate tolerance level of transgenic soybean, $\mathrm{T}_{2}$ plants of Line 1 were planted in the field and sprayed with Roundup at the doses of $900,1800,2700$, and $3600 \mathrm{~g}$ a.e.ha ${ }^{-1}$ respectively. ZH10 and HJ06-698 were used for nontransgenic and transgenic control. One week after glyphosate application, the leaves of non-transgenic control (ZH10) were shriveled severely and showed clear symptoms compared with no treatment of glyphosate (Figures $\mathbf{3 A}, \mathbf{B}$ ). However, all the transgenic plants of Line 1 showed highly tolerance after spraying with 900 to $2700 \mathrm{~g}$ a.e.ha ${ }^{-1}$ glyphosate (Figures 3C-E). When the concentration of glyphosate was reached up to $3600 \mathrm{~g}^{\text {a.e.ha }}{ }^{-1}$, the transgenic plants of Line 1 still grew normally and showed no difference compared with water control (Figure 3F). HJ06-698 which only contained a glyphosate tolerant gene CP4-EPSPS also showed markedly tolerance to glyphosate but appeared "yellow flashing" in the young leaves, as the typical visual symptom of glyphosate application (Figure 3G), the duration of "yellow flashing" were positively correlated with the spraying doses of Roundup (Table 2). After spraying with Roundup at the rate of 900 g a.e.ha ${ }^{-1}$, the time of yellow flashing were continued up to seven to 10 days. However, this time could continue up to 1 to 2 months after spraying at the rate of $3600 \mathrm{~g}$ a.e.ha ${ }^{-1}$.

\section{Tissue and Glyphosate Induced Expression Analysis of Exogenous Gene}

qRT-PCR was used for analysis the target genes expression in different tissues (young leaves, mature leaves, stem, flower, and seed) of Line 1 without glyphosate application or leaves of Line 1 and HJ06-698 treated with $900 \mathrm{~g}$ a.e.ha ${ }^{-1}$ glyphosate at different time points. The highest expression level of target genes was detected in leaves while relative low expression level of transcript in seed and root (Figures 4A,B). After the treatment of glyphosate, no significant variation of transcript accumulation in leaves was detected at any time points when compared with control of no treatment $(0 \mathrm{~h}$; Figure $4 \mathrm{C}, \mathrm{D})$. Moreover, our results also suggested that the expression of G2-EPSPS in leaves of transgenic soybean Line 1 was consisted with that of CP4-EPSPS in HJ06698 (Figure 4E), indicating similar functions of G2-EPSPS and CP4-EPSPS in these transgenic soybeans.

\section{Chlorophyll and Shikimic Acid Content Analysis of Transgenic Soybean}

The chlorophyll contents of leaves in transgenic and nontransgenic soybeans were measured after spraying with labeled rate of Roundup. Compared with control, glyphosate significantly decreased chlorophyll content of non-transgenic soybeans including ZH10 and MD12 (Figures 5A,B). The chlorophyll content of HJ06-698 showed first decreased and then increased trends after spraying with Roundup (Figure 5C). This phenomenon is the results of transient "yellow flashing" in GR1 


\section{A}

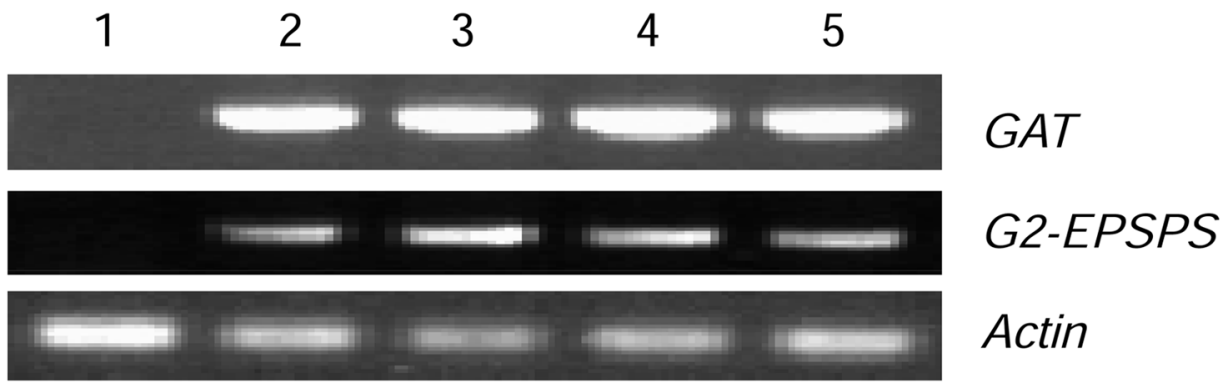

B
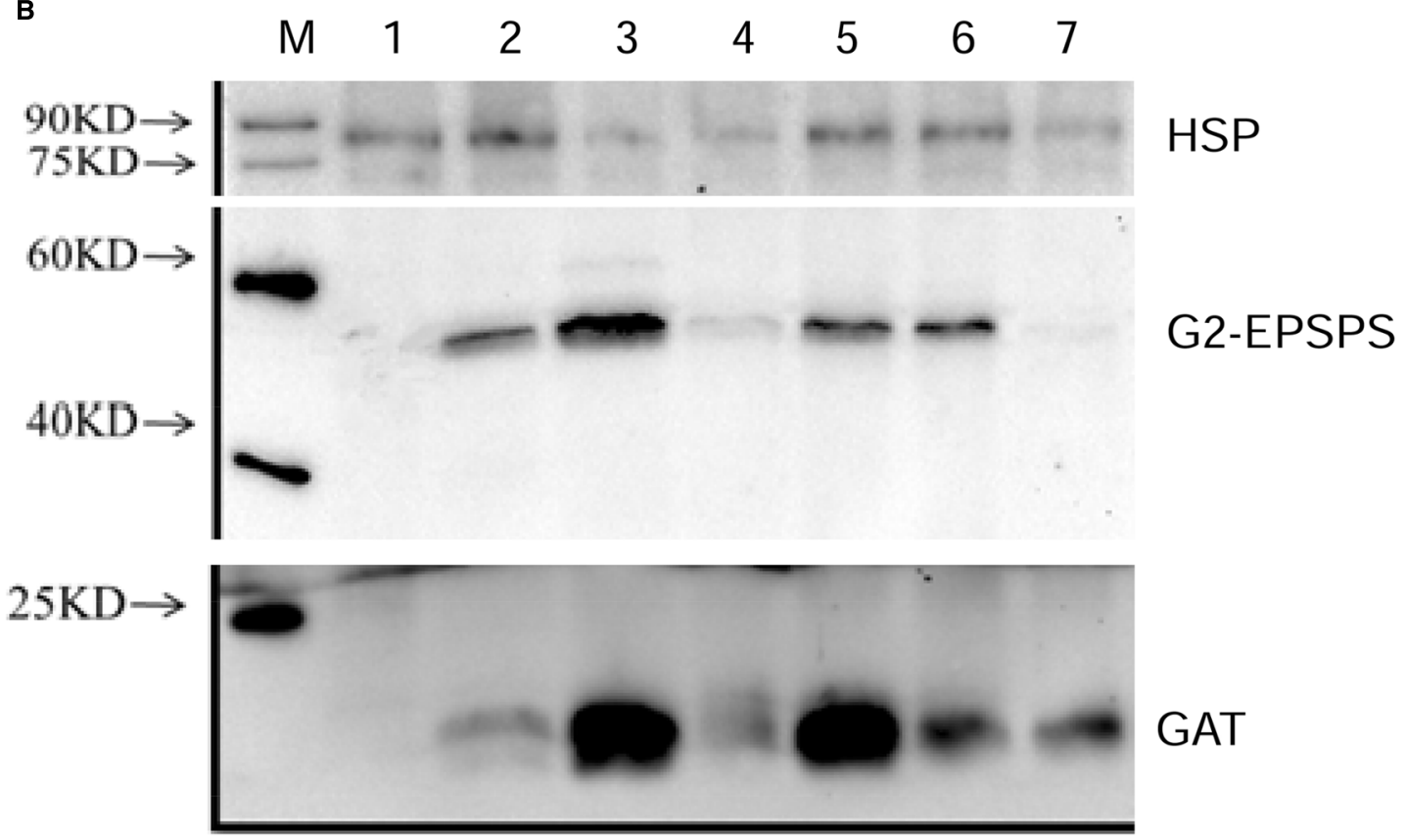

FIGURE 2 | Expression analysis of four transgenic lines by semi quantitative RT-PCR and western blot. (A) The expression of exogenous genes in leaves of four transgenic lines was carried out by semi quantitative RT-PCR. 1: negative control of non-transgenic receptor soybean; 2-5: four putative transgenic lines. (B) Western blot analysis of four transgenic lines, M: Marker; 1: negative control of non-transgenic soybean; 2-4: roots, leaves and stem of transgenic line 1; 5-7: leaves of transgenic line $2-4$.

and GR2 transgenic soybeans. However, transgenic line 1 showed no decrease of chlorophyll content after spraying with Roundup and the trends was similar to water control (Figure 5D), which consistent with the result of no "yellow flashing" phenotype in this transgenic line.

Shikimic acid accumulation as a biomarker was usually used for evaluating the effect of glyphosate. In order to compare the accumulation of shikimic acid in transgenic soybeans, the content of shikimic acid was also measured after treatment with Roundup. The results showed that shikimic acid was significantly increased in non-transgenic plants ZH10 and MD12 after application of glyphosate (Figure 6). The accumulation of shikimic acid in HJ06698 was extremely lower than that of non-transgenic control and showed first increased and then decreased trends. This result was consistent with the phenomenon of "yellow flashing" and the changes of chlorophyll content after treatment of glyphosate. However, accumulation of shikimic acid could not be detected in transgenic line 1 (Figure 6). These results indicated that the phytotoxicity of new transgenic soybean which co-expressed with G2-EPSPS and GAT genes had no or small effect on plant development after application of glyphosate.

\section{DISCUSSION}

At present, most commercial glyphosate tolerance soybeans utilized glyphosate tolerant genes (CP4-EPSPS and $2 \mathrm{~m}$ EPSPS) or glyphosate acetyltransferase gene (GAT 4601) separately (http://www.isaaa.org). CP4-EPSPS was derived from the soil bacterium Agrobacterium sp. Strain CP4 and the enzyme activity of CP4-EPSPS could not be inhibited by glyphosate due to weak binding affinity, resulting in increased tolerance to glyphosate in transgenic plants expressing this gene (Franz et al., 1997; Guicheney et al., 2009; Xiao et al., 2012). GAT encodes an Nacetyltransferase for acetylation of glyphosate, which is the basis 

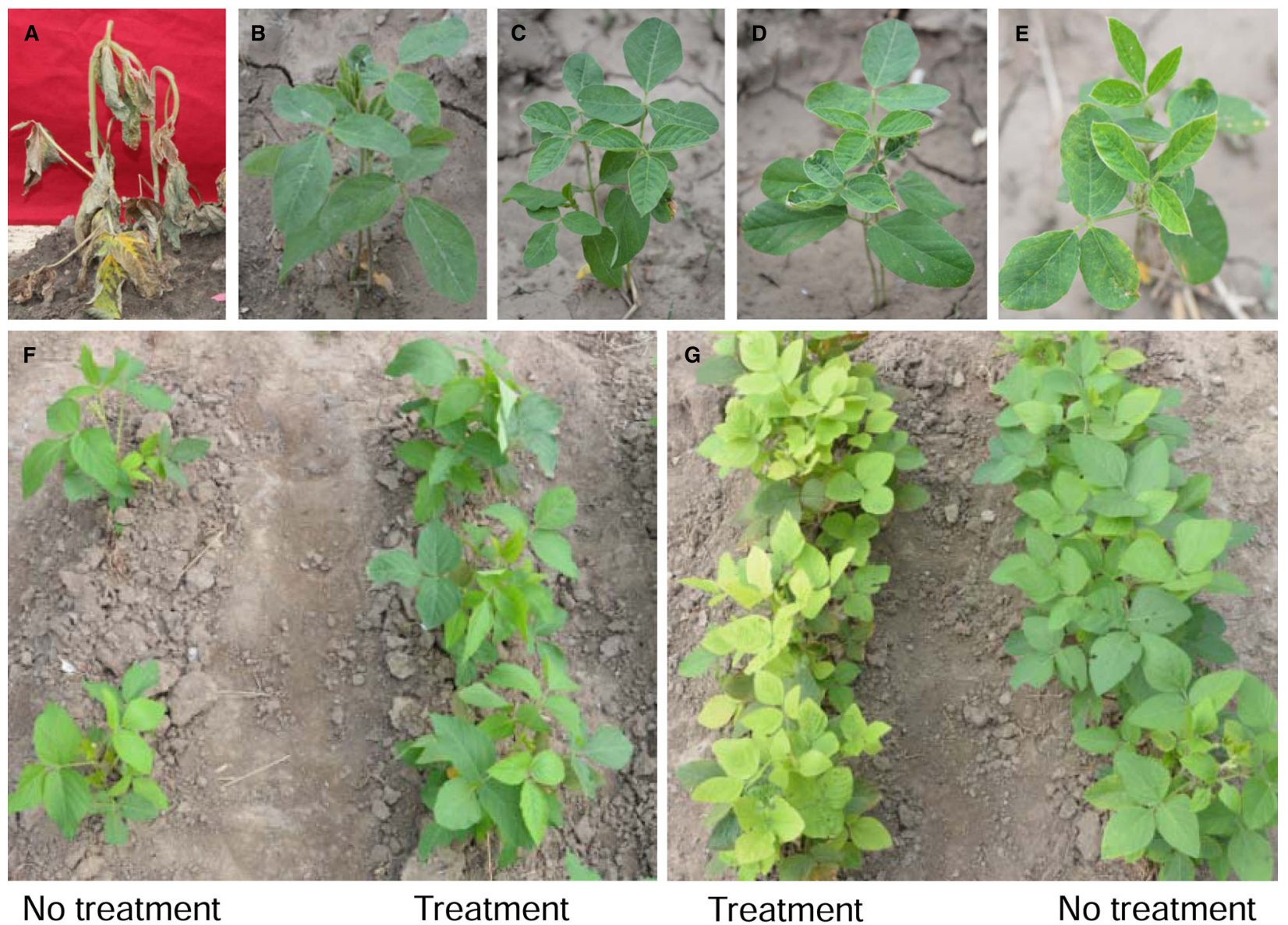

No treatment

Treatment

Treatment

No treatment

FIGURE 3 | Phenotype of line 1 after treatment with glyphosate. ZH10 was sprayed with (A) or without (B) Roundup at the rate of $900 \mathrm{~g}$ a.e.ha ${ }^{-1}$; Line 1 was sprayed with Roundup at the rate of $900 \mathrm{~g}$ a.e.ha ${ }^{-1}$ (C), $1800 \mathrm{~g}$ a.e.ha ${ }^{-1}$ (D), and $2700 \mathrm{~g}$ a.e.ha ${ }^{-1}$ (E); (F) Line 1 was sprayed with or without Roundup at the rate of $3600 \mathrm{~g}$ a.e.ha ${ }^{-1}$; (G) HJ06-698 was sprayed with or without Roundup at the rate of $3600 \mathrm{~g} \mathrm{a.e.ha}^{-1}$.

TABLE 2 | Comparison of tolerance level for transgenic line 1 and HJ06-698.

\begin{tabular}{|c|c|c|c|c|}
\hline GM soybeans & Rates of glyphosate (g a.e.ha ${ }^{-1}$ ) & Tolerance or not & Yellow flashing (Presence/Absence) & Duration (days) \\
\hline \multirow{4}{*}{ Line 1} & 900 & Tolerance & Absence & - \\
\hline & 1800 & Tolerance & Absence & - \\
\hline & 2700 & Tolerance & Absence & - \\
\hline & 3600 & Tolerance & Absence & - \\
\hline \multirow{4}{*}{ HJ06-698 } & 900 & Tolerance & Presence & $9 \pm 2$ \\
\hline & 1800 & Tolerance & Presence & $17 \pm 3$ \\
\hline & 2700 & Tolerance & Presence & $30 \pm 5$ \\
\hline & 3600 & Tolerance & Presence & $45 \pm 15$ \\
\hline
\end{tabular}

of a new mechanism of glyphosate tolerance in GM plants (Castle et al., 2004; Siehl et al., 2005, 2007). Although EPSPS or GAT genes were widely used in commercial glyphosate tolerance crops alone, few researches focused on the new strategy to develop glyphosate tolerance plants by co-expression of these two kinds of genes. Our results suggested that high tolerant transgenic soybeans could be obtained by co-expression of GAT and EPSPS.

For GR1 and GR2 soybeans over-expressing CP4-EPSPS, the labeled rate for glyphosate application is varied from 600 to $1200 \mathrm{~g}$ a.e.ha ${ }^{-1}$ (Gazziero et al., 2008). Although the tolerant level could reach to even threefolds of labeled rate $(2400 \mathrm{~g}$ a.e.ha ${ }^{-1}$ ) at some growth stages, the visual plant injury was often reported in glyphosate tolerant soybeans (Zobiole et al., 2012). In this study, transgenic soybean co-expressed with G2-EPSPS and GAT genes showed high tolerance to glyphosate and the tolerant level could reach to even fourfolds of labeled rate $(3600 \mathrm{~g}$ a.e.ha ${ }^{-1}$ ) with no visual plant injury. Since the activity of EPSP synthase was inhibited by glyphosate and prevent the shikimic acid converted to EPSP, the accumulation of shikimic acid in the young leaves and other tissues of plants usually acts as a marker 


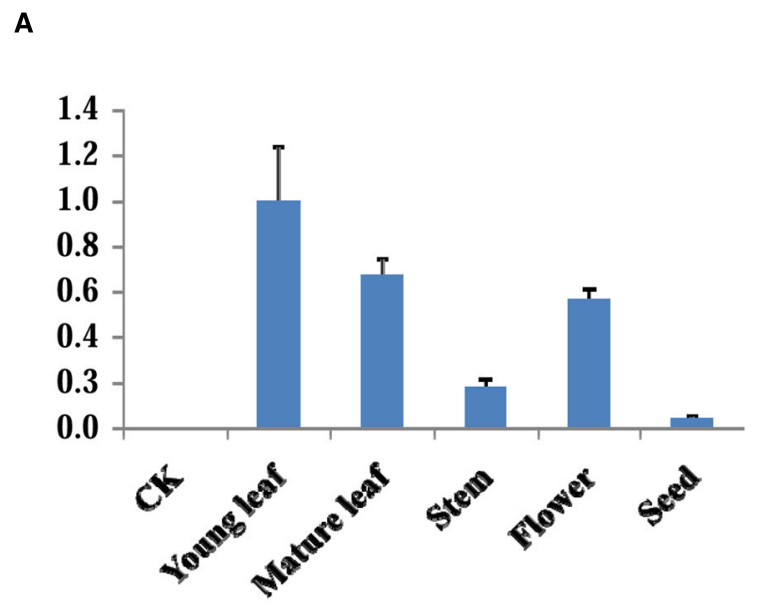

B

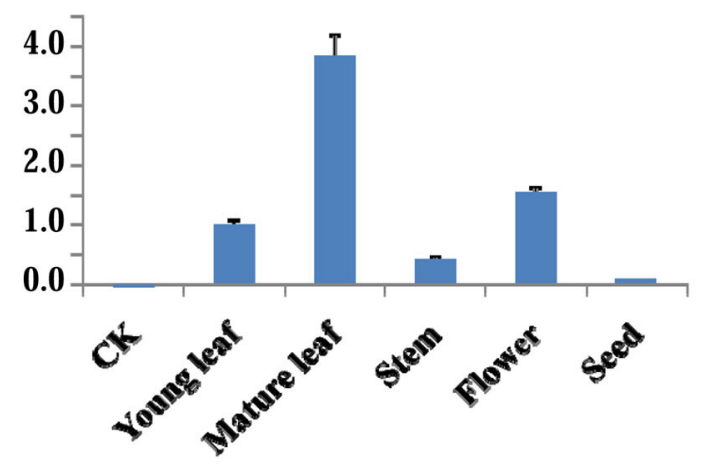

C

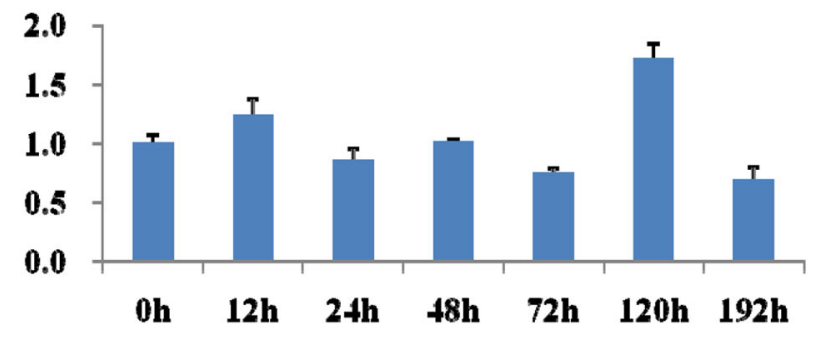

D

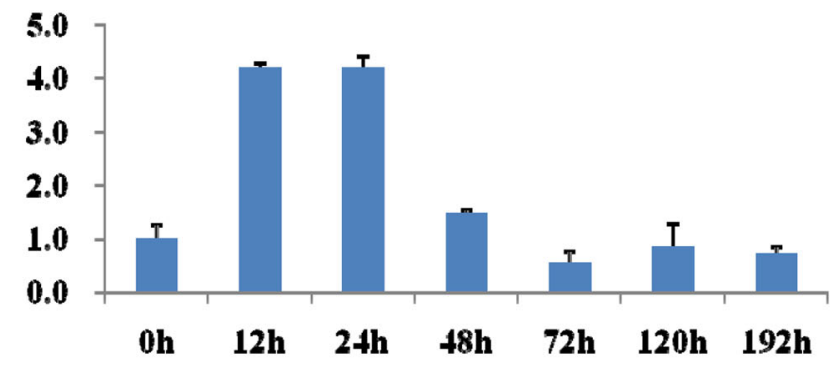

E

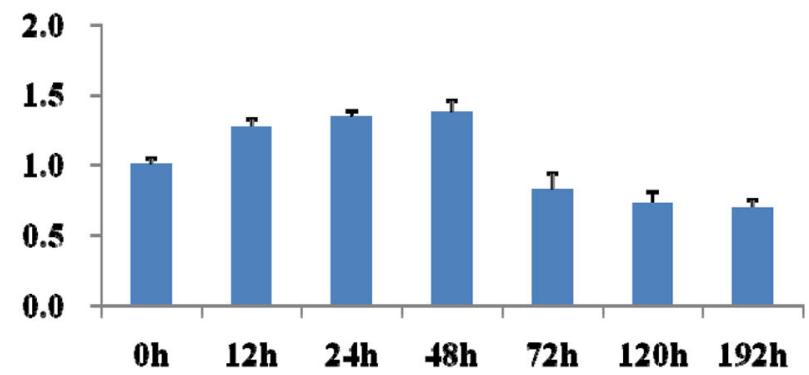

FIGURE 4 | mRNA level of the G2-EPSPS and GAT in transgenic line 1. (A-B) qRT-PCR was used for analysis the expression level of G2-EPSPS gene (A) and GAT gene (B) in different tissues of transgenic soybean line 1. (C-E) qRT-PCR was used for analysis the expression level of GAT (C), G2-EPSPS (D) in leaves of transgenic soybean line 1 and CP4-EPSPS (E) in leaves of HJ06-698 after treatment with $900 \mathrm{~g}$ a.e.ha ${ }^{-1}$ Roundup at different times.

for evaluating the effect of glyphosate (Escorial et al., 2001; Pline et al., 2002; Shaner et al., 2005; Buehring et al., 2007; Henry et al., 2007). Generally, the more shikimic acid the plants accumulated, the more sensitive of the plants to glyphosate is. Therefore, no significant changes of shikimic acid content in transgenic plants co-expressed with G2-EPSPS and GAT genes after treatment with glyphosate resulted in the high tolerance of transgenic line 1 in this study.

Some reports also revealed that the typical symptom of "yellow flashing" and chlorophyll content decrease appeared in both GR1 and GR2 transgenic soybean after the application of glyphosate even at the labeled rate of $800 \mathrm{~g}^{\text {a.e.ha }}{ }^{-1}$ and other glyphosate tolerance plants (Mueller et al., 2003; Zobiole et al., 2010a, 2012). This phenomenon was resulted from the accumulation of primary phytotoxic metabolite (such as shikimic acid) in the plant meristems (Reddy et al., 2004; Ding et al., 2011). Moreover, the photosynthesis, nutrient accumulation, and nodulation in some cultivars of GR2 soybean was also reduced after receiving increasing glyphosate rates and application at later growth stages (Zobiole et al., 2012). In this study, the typical symptom was also observed in HJ06-698 derived from GR1 transgenic soybean even at labeled rate of Roundup
(900 g a.e.ha ${ }^{-1}$ ). After spraying with Roundup, the chlorophyll content of leaves in HJ06-698 was first decreased and then increased (Figure 5). This result was consistent with the variation tendency of shikimic acid content in other glyphosate tolerance cultivars (Zobiole et al., 2011). These changes might be the direct explanation of transient "yellow flashing" in overexpressing CP4EPSPS gene soybeans (Reddy and Zablotowicz, 2003; Zablotowicz and Reddy, 2007). The duration of "yellow flashing" in HJ06698 was positively correlated with the spraying rates of Roundup (Table 2), which were similar to previous reports in corn and soybeans (Mahoney et al., 2014). Although "yellow flashing" is usually considered non-persistent because it tends to disappear within 2 weeks after the application of herbicide (Reddy and Zablotowicz, 2003), the decrease of chlorophyll content direct causes the reduction in photosynthesis and affects nutrient uptake and leads to lower plant biomass production and reduced grain yield (Zobiole et al., 2010b, 2012). In contrary, the typical symptom of glyphosate, such as accumulation of shikimic acid, "yellow flashing" and decreased chlorophyll content were not found in our transgenic plant after the treatment of glyphosate at different rates of 900-3600 g a.e.ha ${ }^{-1}$. This may due to the introduction of GAT besides of EPSPS results 
A

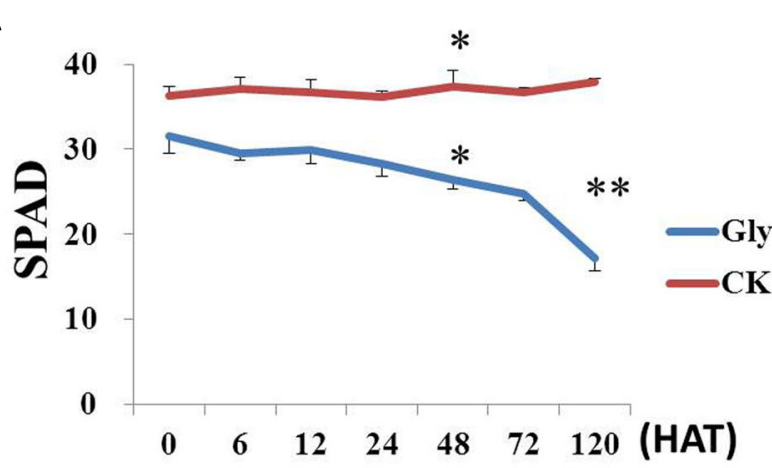

C

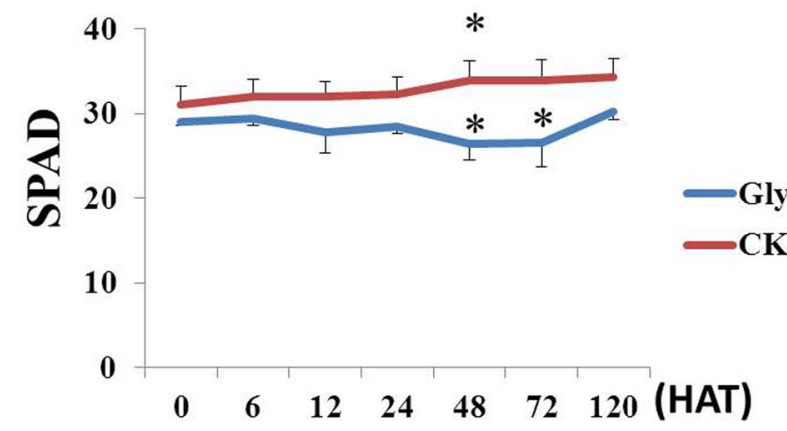

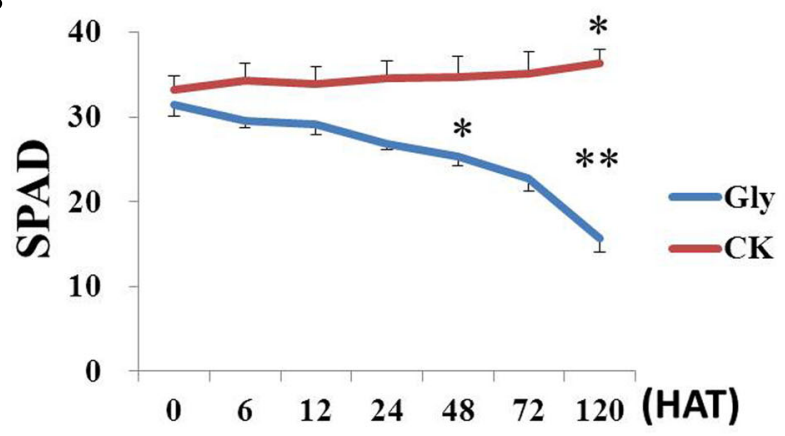

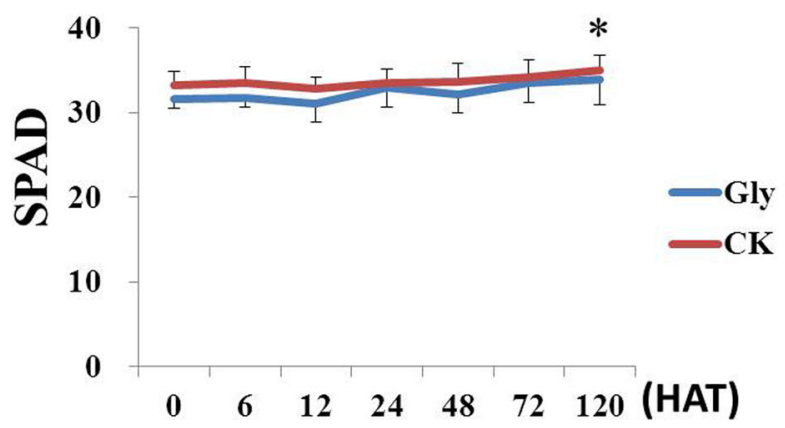

FIGURE 5 | Chlorophyll contents in transgenic plants. Plants spraying with water were used as the negative control (CK) to analysis the chlorophyll content variation in different soybean cultivars after treatment of Roundup with the rate of $900 \mathrm{~g}$ a.e.ha ${ }^{-1}$ (Gly). (A) non-transgenic soybean MD12; (B) non-transgenic soybean ZH10; (C) GR1 transgenic soybean line HJ06-698; (D) transgenic soybean line 1. The difference between treatments has been shown as ${ }^{*} P<0.05$ and ${ }^{* *} P<0.01$

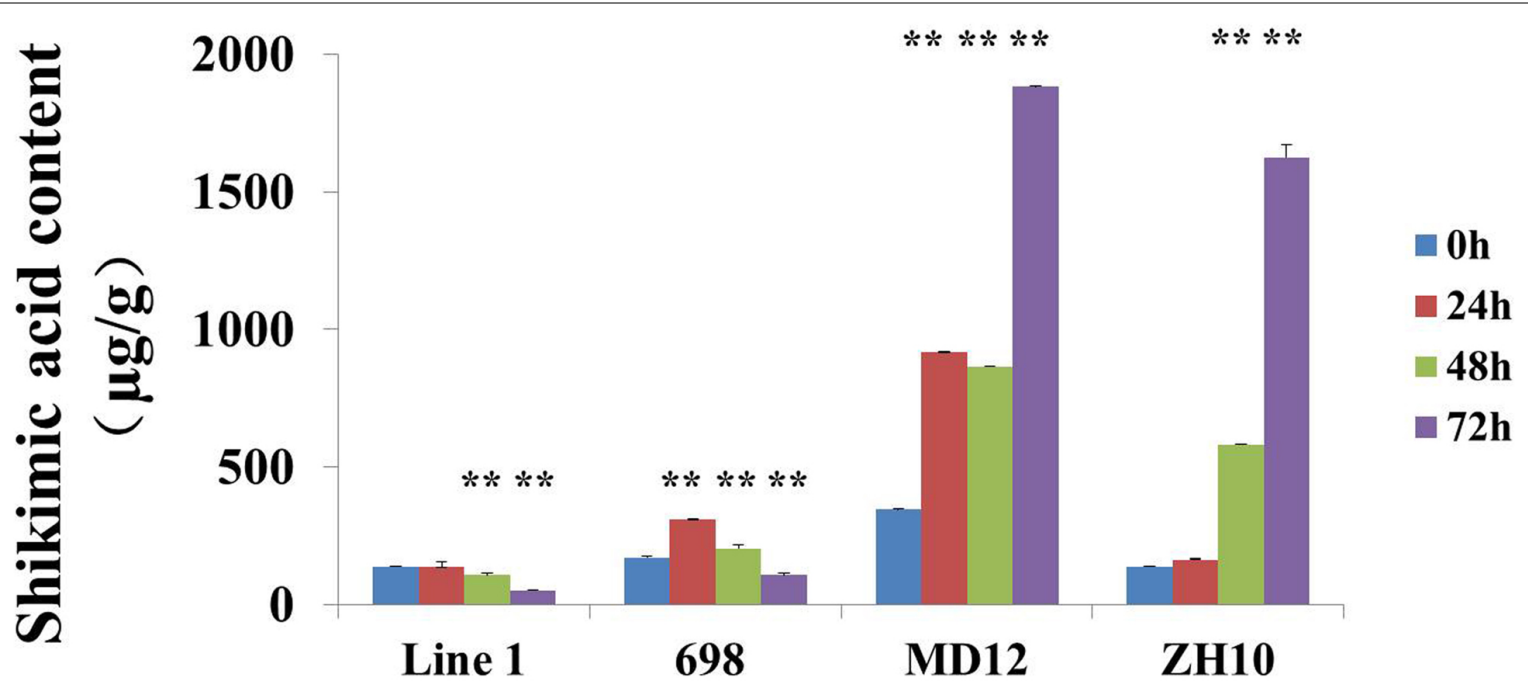

FIGURE 6 | Contents of the shikimic acid in transgenic soybean. The contents of shikimic acid were measured in transgenic soybean line 1, HJ06-698, ZH10, and MD12 after treatment of Roundup with the rate of $900 \mathrm{~g}$ a.e.ha ${ }^{-1}$ for different times. The significance between different times has been shown as ${ }^{\star \star} P<0.01$.

in reducing "true" concentration of glyphosate in soybean organs.

G2-EPSPS was identified from Pseudomonas fluorescens G2 isolated from a storage area with a history of glyphosate pollution and showed high glyphosate tolerance in transgenic tobacco and maize (Zhu et al., 2003; Dun et al., 2007; Liu et al., 2015). Dun et al. (2014) reported that the transgenic tobacco contained G2EPSPS/GAT showed higher tolerance to glyphosate than tobacco contained only G2-EPSPS or GAT alone, and G2-EPSPS carrying tobaccos were significantly more susceptible to glyphosate 
than tobacco contained GAT only. The combination of the metabolic detoxification and target enzyme of glyphosate may result in high tolerance in transgenic crops, providing a new strategy for developing glyphosate tolerant crops. The introduction of detoxification genes like GAT can remove the glyphosate residue, resulting in more robust of tolerance. Moreover, it can also allow farmers to use glyphosate at any stage including reproductive stage of plant development (Pollegioni et al., 2011). In this study, the similar variation of expression level for G2-EPSPS and CP4-EPSPS genes after treatment of glyphosate indicated that these genes perhaps have similar function in transgenic plants. Therefore, the glyphosate detoxification function of GAT might be acts an important role in enhancing the glyphosate tolerance in GM crops.

\section{REFERENCES}

Bradford, M. M. (1976). A rapid and sensitive method for the quantitation of microgram quantities of protein utilizing the principle of protein-dye binding. Anal. Biochem. 72, 248-254. doi: 10.1016/0003-2697(76)90527-3

Buehring, N. W., Massey, J. H., and Reynolds, D. B. (2007). Shikimic acid accumulation in field grown corn (Zea mays) following simulated glyphosate drift. J. Agric. Food Chem. 55, 819-824. doi: 10.1021/jf062624f

Campbell, W. F., Evans, J. O., and Reed, S. C. (1976). Effect of glyphosate on chloroplast ultrastructure of quackgrass mesophyll cells. Weed Sci. 24, 22-25.

Castle, L. A., Daniel, L. S., Gorton, R., Patten, P. A., Chen, Y. H., Bertain, S., et al. (2004). Discovery and directed evolution of a glyphosate tolerance gene. Science 304, 1151-1154. doi: 10.1126/science.1096770

Dill, G. M., CaJacob, C. A., and Padgette, S. R. (2008). Glyphosate-resistant crops: adoption, use and future considerations. Pest Manag. Sci. 64, 326-331. doi: 10.1002/ps.1501

Ding, W., Reddy, K. N., Zablotowicz, R. M., Bellaloui, N., and Bruns, H. A. (2011). Physiological responses of glyphosate-resistant and glyphosatesensitive soybean to aminomethylphosphonic acid, a metabolite of glyphosate. Chemosphere 83, 593-598. doi: 10.1016/j.chemosphere.2010.12.008

Dun, B. Q., Wang, X. J., Lu, W., Chen, M., Zhang, W., Ping, S. Z., et al. (2014). Development of highly glyphosate-tolerant tobacco by coexpression of glyphosate acetyltransferase gat and EPSPS G2-aroA genes. Crop J. 2, 164-169. doi: 10.1016/j.cj.2014.03.003

Dun, B. Q., Wang, X. J., Lu, W., Zhao, Z. L., Hou, S. N., Zhang, B. M., et al. (2007). Reconstitution of glyphosate resistance from a split 5-enolpyruvyl shikimate3-phosphate synthase gene in Escherichia coli and transgenic tobacco. Appl. Environ. Microbiol. 73, 7997-8000. doi: 10.1128/AEM.00956-07

Edwards, R., and Hannah, M. (2014). Focus on weed control. Plant Physiol. 166, 1087-1089. doi: 10.1104/pp.114.900496

Escorial, M. C., Sixto, H., Gracia-Baudin, J. M., and Chueca, M. C. (2001). A rapid method to determine cereal plant response to glyphosate. Weed Technol. 15, 697-702. doi: 10.1614/0890-037X(2001)015[0697:ARMTDC]2.0.CO;2

Franz, J. E., Mao, M. K., and Sikorski, J. A. (1997). Glyphosate: a Unique Global Herbicide. Washington, DC: American Chemical Society.

Gazziero, D. L. P., Adegas, F., and Voll, E. (2008). Glifosate e Soja Transgênica. Circular Técnica 60. Londrina: Embrapa Soja, p4.

Gao, Y., Liu, H., and Tao, B. (2013). Screening for glyphosate resistant wild soybean (Glycine soja) and study in its physiological mechanisms of resistance. Agric. Sci. Technol. 14, 1263-1266.

Green, J. M. (2012). The benefits of herbicide-resistant crops. Pest Manag. Sci. 68, 1323-1331. doi: 10.1002/ps.3374

Green, J. M., Hazel, C. B., Forney, D. R., and Pugh, L. M. (2008). New multipleherbicide crop resistance and formulation technology to augment the utility of glyphosate. Pest Manag. Sci. 64, 332-339. doi: 10.1002/ps.1486

Guicheney, C., Rouquié, D., Freyssinet, M., Currier, T., Martone, A., Zhou, J., et al. (2009). Safety evaluation of the double mutant 5-enolpyruvylshikimate- 3phosphate synthase (2mEPSPS) from maize that confers tolerance to glyphosate herbicide in transgenic plants. Regul. Toxicol. Pharmacol. 54, 143-153. doi: 10.1016/j.yrtph.2009.03.005

\section{AUTHOR CONTRIBUTION}

LQ, YG, and BG conceived and designed the experiments; BG, YG, HH, LJ, and LZ performed the experiments; LQ, YG, BG, RC, WL, and ML analyzed and interpreted the data; LQ, BG, and YG drafted the paper. All authors read and approved the final manuscript.

\section{ACKNOWLEDGMENT}

This work was supported by the National Transgenic Major Program of China (2014ZX08004001) and the Agricultural Science and Technology Innovation Program (ASTIP) of Chinese Academy of Agricultural Sciences.

Guo, B. F., Guo, Y., Wang, J., Zhang, L. J., Jin, L. G., Hong, H. L., et al. (2015). Cotreatment with surfactant and sonication significantly improves Agrobacteriummediated resistant bud formation and transient expression efficiency in soybean. J. Integr. Agric. 14, 1242-1250. doi: 10.1016/S2095-3119(14) 60907-2

Hadi, F., Mousavi, A., Salmanian, A. H., Noghabi, K. A., and Khajeh, K. (2012). Glyphosate tolerance in transgenic canola by a modified glyphosate oxidoreductase (gox) gene. Progr. Biol. Sci. 2, 50-58.

Hartman, G. L., West, E. D., and Herman, T. K. (2011). Crops that feed the world 2. Soybean-worldwide production, use, and constraints caused by pathogens and pests. Food Secur. 3, 5-17. doi: 10.1007/s12571-010-0108-x

Henry, W. B., Shaner, D. L., and West, M. S. (2007). Shikimate accumulation in sunflower, wheat, and prosomillet after glyphosate application. Weed Sci. 55, 1-5. doi: 10.1614/WS-06-065.1

Kenneth, J. L., and Schmittgen, T. D. (2001). A analysis of relative gene expression data using Real-Time quantitativa PCR and the $2^{-\Delta \Delta C}$ T method. Method 25, 402-408. doi: 10.1006/meth.2001.1262

Liu, X. J., He, H. Y., Wang, Y. J., Zhu, S. L., and Piao X. L. (2008). Transesterification of soybean oil to biodiesel using $\mathrm{CaO}$ as a solid base catalyst. Fuel 87, 216-221. doi: 10.1016/j.fuel.2007.04.013

Liu, Y. J., Zhang, Y. W., Liu, Y., Lu, W., and Wang, G. Y. (2015). Metabolic effects of glyphosate on transgenic maize expressing a G2-EPSPS gene from Pseudomonas fluorescens. J. Plant Biochem. Biotechnol. 24, 233-241. doi: 10.1007/s13562-0140263-9

Mahoney, K. J., Nurse, R. E., Everman, W. J., Sprague, C. L., and Sikkema, P. H. (2014). Tolerance of corn (Zea mays L.) to early and late glyphosate applications. Am. J. Plant Sci. 5, 2748-2754. doi: 10.4236/ajps.2014.518291

Meilan, R., Han, K. H., Ma, C., DiFazio, S. P., Eaton, J., Hoien, E. A., et al. (2002). The CP4 transgene provides high levels of tolerance to Roundup ${ }^{\infty}$ herbicide in field-grown hybrid poplars. Can. J. Res. 32, 967-976. doi: 10.1139/ x02-015

Mueller, T. C., Massey, J. H., Hayes, R. M., Chris, L., and Stewart, C. N. (2003). Shikimate accumulates in both glyphosate-sensitive and glyphosate-resistant horseweed (Conyza canadensis L. Cronq.). J. Agric. Food Chem. 51, 680-684. doi: $10.1021 /$ jf026006k

Murray, M. G., and Thompson, W. F. (1980). Rapid isolation of high molecular weight plant DNA. Nucl. Acids Res. 8, 4321-4325. doi: 10.1093/nar/8.19.4321

Padgette, S. R., Re, D. B., Barry, G. F., Eichholtz, D. E., Delanny, X., Fuchs, R. L., et al. (1995). Herbicide-resistant Crops: Agricultural, Economic, Environmental, Regulatory, and Technological Aspects. Boca Raton, FL: CRC/Lewis Publishers.

Pedotti, M., Rosini, E., Molla, G., Moschetti, T., Savino, C., Vallone, B., et al. (2009). Glyphosate resistance by engineering the flavoenzyme glycine oxidase. J. Biol. Chem. 284, 36415-36423. doi: 10.1074/jbc.M109.051631

Pline, W. A., Wilcut, J. W., Duke, S. O., Edmisten, K. L., and Wells R. (2002). Tolerance and accumulation of shikimic acid in response to glyphosate applications in glyphosate-resistant and non-resistant cotton (Gossypium hirsutum L.). J. Agric. Food Chem. 50, 506-512. doi: 10.1021/jf0110699

Pollegioni, L., Schonbrunn, E., and Siehl, D. (2011). Molecular basis of glyphosate resistance-different approaches through protein engineering. FEBS J. 278, 2753-2766. doi: 10.1111/j.1742-4658.2011.08214.x 
Randall, J. M. (1997). "Defining weeds of natural areas," in Assessment and Management of Plant Invasions, eds J. Luken and J. Theiret (New York: Springer Publishing), 18-25. doi: 10.1007/978-1-4612-1926-2_3

Reddy, K. N., Rimando, A. M., and Duke, S. O. (2004). Aminomethylphosphonic acid, a metabolite of glyphosate, causes injury in glyphosate-treated, glyphosateresistant soybean. J. Agric. Food Chem. 52, 5139-5143. doi: 10.1021/jf049605v

Reddy, K. N., and Zablotowicz, R. M. (2003). Glyphosate-resistant soybean response to various salts of glyphosate and glyphosate accumulation in soybean nodules. Weed Sci. 51, 496-502. doi: 10.1614/0043-1745(2003)051[0496:GSRTVS] 2.0.CO;2

Richardson, A. D., Duigan, S. P., and Berlyn, G. P. (2002). An evaluation of noninvasive methods to estimate foliar chlorophyll content. New Phytol. 153, 185-194. doi: 10.1046/j.0028-646X.2001.00289.x

Shaner, D. L., Hassar-Nadler, T., Henry, W. B., and Koger, C. H. (2005). A rapid in vivo EPSPS assay with excised leaf discs. Weed Sci. 53, 769-774. doi: 10.1614/WS05-009R.1

Siehl, D. L., Castle, L. A., Gorton, R., Chen, Y. H., Bertain, S., Cho, H. J., et al. (2005). Evolution of a microbial acetyltransferase for modification of glyphosate: a novel tolerance strategy. Pest Manag. Sci. 61, 235-240. doi: 10.1002/ps.1014

Siehl, D. L., Castle, L. A., Gorton, R., and Keenan, R. J. (2007). The molecular basis of glyphosate resistance by an optimized microbial acetyltransferase. J. Biol. Chem. 282, 11446-11455. doi: 10.1074/jbc.M610267200

Singh, H. B., Singh, B. N., Singh, S. P., and Nautiyal, C. S. (2010). Solidstate cultivation of Trichoderma harzianum NBRI-1055 for modulating natural antioxidants in soybean seed matrix. Biores. Technol. 101, 6444-6453. doi: 10.1016/j.biortech.2010.03.057

Tan, S., Evans, R., and Singh, B. (2006). Herbicidal inhibitors of amino acid biosynthesis and herbicide-tolerant crops. Amino Acid 30, 195-204. doi: 10.1007/s00726-005-0254-1

Tian, Y. S., Xu, J., Xiong, A. S., Zhao, W., Fu, X. Y., Peng, R. H., et al. (2011). Improvement of glyphosate resistance through concurrent mutations in three amino acids of the Ochrobactrum 5-enopyruvylshikimate-3-phosphate synthase. Appl. Environ. Microbiol. 77, 8409-8414. doi: 10.1128/AEM.05271-11

Xiao, X., Wu, H., Zhou, X., Xu, S., He, J., Shen, W., et al. (2012). The combination of quantitative PCR and western blot detecting CP4-EPSPS component in Roundup Ready soy plant tissues and commercial soy-related food stuffs. J. Food Sci. 77, C603-C608. doi: 10.1111/j.1750-3841.2012.02718.x
Yao, T. H. (2009). Chemical weeding in the soybean field. J. Shanxi Agric. Sci. $37,96$.

Young, V. R. (1991). Soy protein in relation to human protein and amino acid nutrition. J. Am. Diet. Assoc. 91, 828-835.

Zablotowicz, R. M., and Reddy, K. N. (2007). Nitrogenase activity, nitrogen content, and yield responses to glyphosate in glyphosate-ressistant soybean. Crop Prot. 26, 370-376. doi: 10.1016/j.cropro.2005.05.013

Zhang, Z. F. (2011). The application of chemical herbicides in forestry projects. Sci. Inform. Dev. Eco. 21.

Zhu, Y., Yu, Z. L., and Lin, M. (2003). Bioresistance or biodegradation of glyphosate and construction of transgenic plants. Mol. Plant Breeding 1, 435-441.

Zobiole, L. H. S., Kremer, R. J., Oliveira, R. S., and Constantin, J. (2010a). Glyphosate affects photosynthesis in first and second generation of glyphosate-resistant soybeans. Plant Soil. 336, 251-265. doi: 10.1007/s11104-010-0474-3

Zobiole, L. H. S., Oliveira, R. S., Kremer, R. J., Constantin, J., Yamada, T., Castro, C., et al. (2010b). Effect of glyphosate on symbiotic N2 fixation and nickel concentration in glyphosate-resistant soybeans. Appl. Soil Ecol. 44, 176-180. doi: 10.1016/j.apsoil.2009.12.003

Zobiole, L. H. S., Kremer, R. J., Oliverira, R. S., and Constantin, J. (2011). Glyphosate affects chlorophyll, nodulation and nutrient accumulation of "second generation" glyphosate-resistant soybean (Glycine max L.). Pest. Biochem. Physiol. 99, 53-60. doi: 10.1016/j.pestbp.2010.10.005

Zobiole, L. H. S., Kremer, R. J., Oliveira, R. S., and Constantin, J. (2012). Glyphosate effects on photosynthesis, nutrient accumulation, and nodulation in glyphosate-resistant soybean. J. Plant Nutr. Soil Sci. 175, 319-330. doi: 10.1002/jpln.201000434

Conflict of Interest Statement: The authors declare that the research was conducted in the absence of any commercial or financial relationships that could be construed as a potential conflict of interest.

Copyright (c) 2015 Guo, Guo, Hong, Jin, Zhang, Chang, Lu, Lin and Qiu. This is an open-access article distributed under the terms of the Creative Commons Attribution License (CC BY). The use, distribution or reproduction in other forums is permitted, provided the original author(s) or licensor are credited and that the original publication in this journal is cited, in accordance with accepted academic practice. No use, distribution or reproduction is permitted which does not comply with these terms. 